ejusque semissem restituit: Hipparchi solius ab orbe condito vel diis improbos in octava duntaxat gradus parte conatus longissime antegressus : utriusque luminaris cursum exquisite restauravit, pro reliquis el raticis solidissima tabularum Rudolphaearum fundamenta jecit: Mathematicarum rerum peritis inveteratam Aristotelis et asseclarum doctrinam de sublunari cometarum novorumque siderum situ, demonstrationibus invictis exemit : novarum hypothesium autor; in Stagyricis et universa philosophia admirandus; evocatus ab invictissimo Romano imperatore Rudolpho Secundo, mira doctrinæ et candoris exempla dedit; ne frustra vixisse videretur, immortalitatem, etiam apud Antipodas scriptorum perennitate sibi comparavit; planeque qualis esse quam haberi maluit, nunc vita functus æternum vivit.

Ejus exuvias uxorisque triennio post defunctæ heredes liberi sacro hoc loco composuerunt. Obiit quarto kalend. Novembris anni Christiani Dionysiaci MDCI ætatis suæ. LV.

Non fasces, nec opes, sola artis sceptra perennant." Around the tombstone bearing Tycho's likeness we read: "Anno Domini MDCI die XXIV Octobris obiit illustris et generosus Dominus Tycho Brahe, Dominus in Knudstrup et Præses Uraniburgi et sacræ Cæsareæ Majestatis Consiliarius, Cujus ossa hic requiescunt."

When the visit to Tycho's tomb took place, the Mayor of Prague laid a beautiful wreath upon the tomb which bore the inscription upon ribbons in national colours, "To the great philosopher-the Royal Capital of Prague." Other wreaths bore the inscriptions, "Universitas Hafniensis," "Societas regia scientiarum Danica," "Fra Danske Studenter." There were also wreaths from Prof. Săfarik, the Observatory of Prague, and many others from literary and scientific societies.

The visitors afterwards proceeded to a house on the "Fruit Market," where a memorial tablet of marble was placed stating that Kepler lived there from 1604-1607. In the afternoon the Belvedere of Tycho Brahe was visited and a name "Tycho. Street" was given to a new street opposite it. The long row of carriages bearing the numerous visitors then proceeded to a quiet street near the now abandoned Royal Castle, and the house "At the Golden Griffin" was shown, having in front a marble tablet stating that Tycho lived there in 1600 and 160I. Finally, the place was visited where Tycho's last observatory formerly stood and where a new street, bearing the name of Kepler, is now situated.

In this way was celebrated the memory of the great astronomer whose work marks a great epoch in that science, and from whose observations his friend and colleague Kepler calculated his well-known laws.

BOHUSLAV BRAUNER.

Celebrations in DenMaRK AND Sweden.

In Copenhagen the Society of Science celebrated the tercentenary of Tycho Brabe's death in the presence of the King and Royal family and all the members of the Society. The meeting was opened with a short address by the president of the Society, Prof. Jul. Thomsen, who announced that Dr. J. L. E. Dreyer, who was born in Denmark, had had the order of Knight of the Dannebrog conferred upon him by the King. Prof. Fridericia gave a lecture on the personality of Tycho Brahe. He pointed out his scientific enthusiasm and his accurate observations, and showed how towards the close of his life he neglected the mystical side of astrology and regarded astronomy more from the physical point of view. The astronomer's statue in the grounds of the Copenhagen Observatory was decked with wreaths and flowers.

At the University of Lund a bust of Tycho Brahe was unveiled. The Stockholm Academy of Science celebrated the event by a memorial festival in the presence of Prince Eugen and several of the ministers, when speeches were delivered by President Odhner and Prof. Dunér.

No. I67 I, VOL. 65$]$
STUDIES ON THE ETHNOGRAPHY OF THE NORTH QUEENSLAND ABORIGINES. ${ }^{1}$

$A$ NTHROPOLOGISTS so fully recognised the value $\mathrm{A}$ of Dr. Walter E. Roth's "Ethnological Studies among the North-West-Central Queensland Aboriginals" that there was considerable satisfaction when the news arrived a year or two ago of his appointment as Northern Protector of Aboriginals in Queensland. We now have the pleasure of receiving two Bulletins on North Queensland ethnography, which are the first-fruits of that able investigator's researches in his new sphere, and at the same time we must thank and compliment the Home Secretary's Department in Brisbane for issuing these Bulletins, especially as we are promised two or three similar Bulletins annually. Dr. Roth expresses his deep indebtedness to the Hon. J. F. G. Foxton for all the kindly encouragement invariably received from him during the prosecution of his scientific labours, and it is due to his wishes, as ministerial head of the Department, that these researches of Dr. Roth's are now being made available to the public. Dr. Roth has anticipated the thanks which anthropologists at home would like to offer to this publicspirited Minister. Publications such as these will do something towards reducing that ignorance of our native races which is largely die to the apathy of our Government as a whole.

The first Bulletin consists of an essay by Dr. Roth on "String, and other Forms of Strand: Basketry-, Woven bag- and Net-work." The animal and vegetable products of which strings are made are enumerated, and $\mathrm{Mr}$. F. M. Bailey, the Colonial botanist, has identified the plants from which textiles are made which have been collected by Dr. Roth. The method of making string, including the manufacture of human-hair twine, is fully described and illustrated. Dr. Roth gives in his short direct style accounts of the procedures in which string and other forms of strand are employed. His classification of the processes of construction of basketry, woven bags and network will prove of considerable value to those who have to describe similar textiles from other countries. His explanations are illustrated by nearly a hundred clear diagrams drawn by the author and contained in nineteen plates.

The second Bulletin is devoted to the structure of the Koko-Yimidir language, in which Dr. Roth has had the invaluable cooperation of the Revs. G. H. Schwarz and W. Poland, Lutheran missionaries at Cape Bedford Mission Station. This language is spoken from the Annan and Endeavour Rivers to the northern side of Cape Flattery. It is noteworthy that this Koko-Yimidir language is the identical one of which Lieutenant Cook took a vocabulary when visiting the Endeavour River in 1770 . A table is given of Cook's words with those in use at the present day; the "kanguroo" of the great voyager is still spoken of as ganguru. There are many suggestive notes on the language apart from the interest of the language itself.

We have no doubt that the succeeding numbers will be as valuable as those now to hand, and we shall eagerly await the good things which we are sure Dr. Roth has in store for us.

\section{CHARLES MELDRUM.}

DR. CHARLES MELDRUM was born at Kirkmichal, Banffshire, in $182 \mathrm{I}$, and died in Edinburgh in August Igor. He was educated at Aberdeen University, and after graduation as Master of Arts he joined the Bombay Education Department. In 1848 he was appointed professor of mathematics in the Royal College

1 " North Queensland Ethnography." Bulletin No. 1, C.A. II-igor, price $8 s$. : No. 2, C.A. 22-1901, price 1s. (Brisbane:' by Authority Edmund Gregory, Government Priuter, William Street Igol.) $^{2}$ 